\title{
Primary Localized Amyloidosis of the Bladder Mimicking Neoplasia
}

\author{
Neoplaziyi Taklit Eden Mesanenin Primer Lokalize Amiloidozisi
}

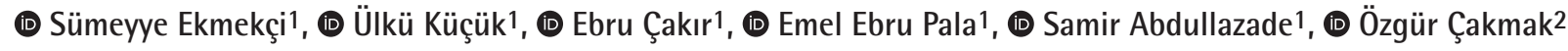 \\ 1 University of Health Sciences, İzmir Tepecik Training and Research Hospital, Clinic of Pathology, Izmir, Turkiye \\ 2 University of Health Sciences, Izmir Tepecik Training and Research Hospital, Clinic of Urology, Izmir, Turkiye
}

\begin{abstract}
A 63-year-old woman was admitted to our hospital with macroscopic hematuria in 2013. On computed tomography, the bladder wall thickness was $2 \mathrm{~cm}$, suspicious for malignancy. Cystoscopy showed irregularity in the posterolateral side of the bladder. Transurethral resection was performed. Histopathological examination revealed a dense homogeneous eosinophilic material in the lamina propria which showed positive orange-red staining with apple-green birefringence under polarized light. There were no signs of systemic amyloidosis at the time of diagnosis and during the 36 months of follow-up. Differential diagnosis of amyloidosis in the bladder includes urothelial carcinoma due to its appearance on imaging and cystoscopy. Histopathological evaluation is a requirement for accurate diagnosis.
\end{abstract}

Keywords: Primary, Amyloidosis, Bladder

\section{Öz}

Altmış üç yaşında kadın hasta 2013 yılında makroskopik hematüri ile hastanemize başvurdu. Bilgisayarlı tomografide, mesane duvarının posterolateral ve superior kısmının, tümör açısından şüphe uyandıracak şekilde $2 \mathrm{~cm}$ kalınlığında olduğu görüldü. Sistoskopik bakıda mesanenin posterolateral tarafında düzensiz alanlar görüldü. Transüretral mesane rezeksiyonu ile kürete materyal elde edildi. Biyopside lamina propriada turuncu-kırmızı boyanma gösteren, yoğun, homojen eozinofilik materyal izlendi ve polarizasyonda elma yeşili çift kırılımı gösterildi. Olguda tanı anında ve 36 aylık takiplerinde sistemik amiloidoz bulguları saptanmadı. Mesanenin amiloidozu, görüntüleme yöntemlerinde ve sistoskopide ürotelyal karsinom ile kolayca karışabilen nadir bir durumdur. Kesin tanı için histopatolojik inceleme şarttır.

Anahtar Kelimeler: Primer, Amiloidoz, Mesane

\section{Introduction}

Amyloidosis is a disorder caused by extracellular deposition of insoluble fibrils composed of misaggregated proteins (1). Primary amyloidosis of the urinary bladder is an extremely rare entity with less than 200 cases reported worldwide (2). The lesion can easily mimic malignancy because of its appearance on radiological examination and cystoscopy $(3,4,5)$. Histopathological evaluation is necessary to exclude malignancies. We report a 63-year-old female who was admitted to our hospital with hematuria and received the histopathological diagnosis of amiloidosis.

\section{Case Presentation}

A 63-year-old female patient was admitted to our hospital with macroscopic hematuria. Computed tomography showed urinary bladder wall thickness of $2 \mathrm{~cm}$ in the posterolateral and superior wall of the bladder, suspicious for malignancy. Cystoscopy showed irregularity in the posterolateral wall of the bladder. Transurethral resection was performed. Histopathological examination revealed a dense homogenous eosinophillic material in the lamina propria showing positive orange-red staining with Congo-red with apple-green birefringence under polarized light (Figure 1). There was no evidence of urothelial neoplasia or precursor lesion. There was no sign of systemic amyloidosis at the time of diagnosis and during the 36 months

Correspondence: Sümeyye Ekmekçi MD, University of Health Sciences, İzmir Tepecik Training and Research Hospital, Clinic of Pathology, İmir, Turkiye E-mail: ekmekcisumeyye@gmail.com ORCID-ID: orcid.org/0000-0003-1607-500X Received: 18.04.2017 Accepted: 25.04.2017

Cite this article as: Ekmekçi S, Küçük Ü, Çakır E, Pala EE, Abdullazade S, Çakmak Ö. Primary Localized Amyloidosis of the Bladder Mimicking Neoplasia. J Urol Surg 2018;5(2):120-122.

- Copyright 2018 by the Association of Urological Surgery / Journal of Urological Surgery published by Galenos Publishing House. 

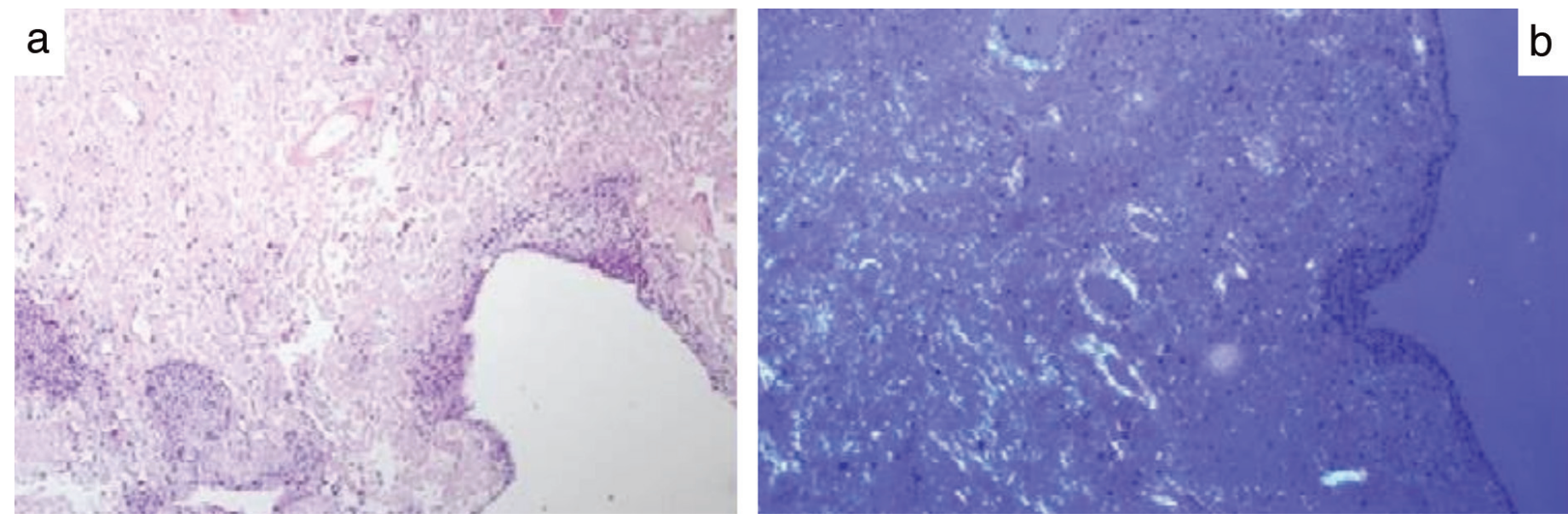

Figure 1. (a) Deposits of eosinophilic, acellular material in the lamina propria beneath urothelial epithelial layer (hematoxylin and eosin stain, 400x). (b) Apple green birefringence of amyloid deposits under polarized microscopy (congo red stain, 400x)

of follow-up. However, 36 months later, she presented with a second episode of macroscopic hematuria and underwent transurethral resection. Histopathological examination showed amiloid deposition in the lamina propria of the bladder wall.

Informed consent was obtained from the patient.

\section{Discussion}

Amyloidosis is a benign, non-neoplastic disease characterized by extracellular deposition of eosinophilic fibrillar proteins in various tissues and organs (6). In the urinary tract, amyloid deposition may occur in the kidney, renal pelvis, ureters, urinary bladder, urethra and even in the penis (4).

Both sexes are equally affected, most commonly during the fifth and seventh decades of life (4). The most frequent symptom of amyloidosis in the bladder is gross haematuria (7). Irritative voiding symptoms have been reported in $23 \%$ of cases in various studies (8). Since it predominantly involves the submucosal and muscular layers, massive hemorrhage is a rare occurrence (4).

Cystoscopic examination of bladder amyloidosis often shows yellowish plaques or tumor-like structures (9).

Histopathological examination demonstrates a dense acellular homogenous eosinophillic material showing positive orangered staining with Congo-red with apple-green birefringence under polarized light.

Amyloidosis is classified as primary amyloidosis (AL), secondary amyloidosis (AA) and transthyretin-related amyloidosis (ATR) $(9,10,11)$. Amyloidosis can be either localized or systemic $(9,10,11)$. Localized deposition of amyloid may occur in any organ in the absence of systemic involvement (12). Primary localized amyloidosis of the urinary bladder is uncommon, however, the bladder is the most common site of involvement
$(3,4)$. Primary amyloidosis is also the most common form of localized amyloidosis in the bladder (11).

The treatment modality in primary bladder amyloidosis is usually conservative with transurethral resection, but high recurrence rate of almost $50 \%$ has been described (7). In some patients with irritative symptoms or gross haemeturia, cystectomy is necessary (7). Medical treatment, such as colchicines, nitrofuazone and dimethylsulfoxide as primary or adjuvant therapy, has been tried for symptomatic relief (4).

Amyloidosis of the bladder is a rare condition which mimics urothelial carcinoma because of its appearance on imaging as well as cystoscopy. Histopathological evaluation is essential for definitive diagnosis and management.

\section{Ethics}

Informed Consent: Informed consent was obtained from the patient.

Peer-review: Externally and internally peer-reviewed.

\section{Authorship Contributions}

Surgical and Medical Practices: S.E., Ü.K., E.Ç., Ö.Ç., Concept: S.E., Ü.K., E.Ç., Design: S.E., Ü.K., Data Collection or Processing: S.E., Ü.K., E.Ç., E.E.P., S.A., Ö.Ç., Analysis or Interpretation: S.E., Ü.K., Literature Search: S.E., Ü.K., E.Ç., E.E.P., S.A., Ö.Ç., Writing: S.E., Ü.K.

Conflict of Interest: No conflict of interest was declared by the authors.

Financial Disclosure: The authors declared that this study received no financial support.

\section{References}

1. Hazenberg BP. Amyloidosis: a clinical overview. Rheum Dis Clin North Am 2013;39:323-345. 
2. Merrimen JL, Alkhudair WK, Gupta R. Localized amyloidosis of the urinary tract: case series of nine patients. Urology 2006;67:904-909.

3. Livneh A, Shtrasburg S, Martin BM, Baniel J, Gal R, Pras M. Light chain amyloidosis of the urinary bladder: a site restricted deposition of an externally produced immunoglobulin. J Clin Pathol 2001;54:920-923.

4. Karan SC, Shah AK, Srivastava A, Bhardwaj R. Primary amyloidosis of urinary bladder: Mimicking transitional cell carcinoma bladder? Med J Armed Forces India 2016;72:91-93.

5. Palmero Marti JL, Budia Alba J, Arlandis Guzman S, Benedicto Redon A, Hernandez Marti M, Jimenez Cruz JF. Secondary vesical amyloidosis. Actas Urol Esp 2004;28:238-242.

6. Jain M, Kumari N, Chhabra P, Gupta RK. Localized amyloidosis of urinary bladder: A diagnostik dilemma. Indian J Pathol Microbiol 2008;51:247-249.

7. Hosseini A, Ploumidis A, Adding C, Wiklund NP. Radical surgery for treatment of primary localized bladder amyloidosis: could prostate-sparing robot assisted cystectomy with intracorporeal urinary diversion be an option? Scand J Urol 2013;47:72-75.
8. Khan SM, Birch PJ, Bass PS, Williams JH, Theaker JM. Localized amyloidosis of the lower genitourinary tract: a clinicopathological and immunohistochemical study of nine cases. Histopathology 1992;21:143147.

9. Kawashima A, Alleman WG, Takahashi N, Kim B, King BF Jr, LeRoy AJ. Imaging evaluation of amyloidosis of theurinary tract and retroperitoneum. Radiographics 2011;31:1569-1582.

10. Monge $M$, Chauveau $D$, Cordonnier $C$, Noël LH, Presne $C$, Makdassi $R$, Jauréguy $M$, Lecaque $C$, Renou M, Grünfeld JP, Choukroun G. Localized amyloidosis of the genitourinary tract: report of 5 new cases and review of the literature. Medicine (Baltimore) 2011;90:212-222.

11. Schou-Jensen KS, Dahl C, Pilt AP, Azawi NH. Amyloidosis the bladder: three cases with different appearance. Scand J Urol 2014;48:489-492.

12. Kobayashi T, Roberts J, Levine J, Degrado J. Primary bladder amyloidosis. Intern Med 2014;53:2511-2513. 